- Original Article-

\title{
Different effects of an extended photoperiod treatment on growth, gonadal function, and condition of hair coats in Thoroughbred yearlings reared under different climate conditions
}

\author{
Tsuyoshi SUZUKI ${ }^{1 \#}$, Hirotoshi MIZUKAMI ${ }^{2 \#}$, Yasuo NAMBO $^{3,4}$, Mutsuki ISHIMARU ${ }^{5}$, \\ Kenji MIYATA $^{5}$, Kentaro AKIYAMA ${ }^{5}$, Kenji KOROSUE ${ }^{6}$, Hiroshi NAITO ${ }^{7}$, \\ Kentaro NAGAOKA ${ }^{4,8}$, Gen WATANABE ${ }^{4,8}$ and Kazuyoshi TAYA ${ }^{8,9 *}$ \\ ${ }^{1}$ Donan NOSAI, Hokkaido 049-3521, Japan \\ ${ }^{2}$ Ritto Training Center, Japan Racing Association, Shiga 520-3085, Japan \\ ${ }^{3}$ Department of Clinical Veterinary Science, Obihiro University of Agriculture and Veterinary Medicine, Hokkaido \\ 080-8555, Japan \\ ${ }^{4}$ United Graduate School of Veterinary Sciences, Gifu University, Gifu 501-1 193, Japan \\ ${ }^{5}$ Hidaka Training and Research Center, Japan Racing Association, Hokkaido 057-0171, Japan \\ ${ }^{6}$ Miyazaki Yearling Training Farm, Japan Racing Association, Miyazaki 880-0036, Japan \\ ${ }^{7}$ Equine Department, Japan Racing Association, Tokyo 105-0003, Japan \\ ${ }^{8}$ Laboratory of Veterinary Physiology, Cooperative Department of Veterinary Medicine, Faculty of Agriculture, Tokyo \\ University of Agriculture and Technology, Tokyo 183-8509, Japan \\ ${ }^{9}$ Shadai Corporation, Hokkaido 059-1432, Japan
}

\begin{abstract}
One- to two-year-old Thoroughbred colts and fillies being reared in Miyazaki (warm climate) and Hidaka (cold climate), Japan, were administered extended photoperiod (EP) treatment between December 20 and the following April 10, and its effect on growth, endocrine changes, gonadal activation, and hair coat condition was investigated. In colts reared in Miyazaki, no effect of EP treatment was noted on the growth indices, including body weight $(B W)$, height at withers $(H W)$, girth, and cannon circumference (CC), whereas the BWs and CCs of fillies were significantly higher in the EP treatment group than the control. In Hidaka, the BWs and HWs of colts and HWs of fillies were significantly higher in the EP treatment group. Gonadal activation characterized by an increase in circulating hormone concentrations was earlier in the EP treatment group for fillies reared in Miyazaki [luteinizing hormone (LH), follicle-stimulating hormone $(F S H)$, progesterone $\left(P_{4}\right)$, and estradiol-17ß $\left.\left(E_{2}\right)\right]$ and in colts $(L H$, testosterone, and $\left.E_{2}\right)$ and fillies ( $L H, F S H, P_{4}$, and $\left.E_{2}\right)$ reared in Hidaka. Regardless of sex and climate, prolactin was significantly higher in the EP treatment group, whereas insulin-like growth factor (IGF-I) was not. Initial ovulation occurred before April in more of the EP treatment group than the control regardless of the climate. Molting of the hair coat, examined in March, was advanced in the EP treatment group regardless of sex and climate. These results suggest that EP treatment may promote growth and gonadal activation in fillies reared in Miyazaki and in colts and fillies reared in Hidaka and that the effect may be mediated by prolactin.
\end{abstract}

Key words: climate, growth, extended photoperiod treatment, testis and ovary, Thoroughbred colt and filly

Received: April 16, 2015

Accepted: October 23, 2015

*Corresponding author. e-mail: taya@cc.tuat.ac.jp

\#These authors contributed equally to this work.

(C)2015 Japanese Society of Equine Science

This is an open-access article distributed under the terms of the Creative Commons Attribution Non-Commercial No Derivatives (bync-nd) License $<$ http://creativecommons.org/licenses/by-nc-nd/3.0/>.
J. Equine Sci. Vol. 26, No. 4 pp. 113-124, 2015
Race horses are expected to have achieved a certain level of physical maturity. At production sites, extended photoperiod (EP) treatment is applied to broodmares to advance the breeding season and achieve conception and delivery earlier than in those under natural conditions. It has recently been reported that EP treatment was applied for rearing horses 
at Hidaka Training and Research Center (Hidaka), Japan Racing Association (JRA), and that it advanced activation of gonadal function and coat molting and increased the muscle mass $[45,50]$. In Japan, it is well known at production and rearing sites that southland horses grow faster than northland horses. Comparison of the growth of Thoroughbred colts and fillies reared under natural light between Miyazaki Yearling Training Farm (Miyazaki), JRA, and Hidaka clearly showed that both Thoroughbred colts and fillies reared in Miyazaki grew faster than those reared in Hidaka [45]. In addition, colts and fillies reared in Miyazaki showed faster development of testicular function and earlier ovulation, respectively, than those reared in Hidaka, clarifying the earlier promotion of gonadal function in Miyazaki [45].

The present study, therefore, was designed to clarify whether the promotion of growth, gonadal functions, and condition of the hair coat can be induced by EP treatment in Thoroughbred colts and fillies reared in Miyazaki. The results were compared with those of colts and fillies reared in Hidaka. In addition, endocrine changes induced by EP treatment were investigated to clarify the mechanism responsible for effects of EP treatment on physical condition of yearlings.

\section{Materials and Methods}

\section{Animals}

For analysis of growth and gonadal function, 48 Thoroughbreds born in Hokkaido and Aomori Prefectures were divided into two groups, with 24 horses (12 colts and 12 fillies) being reared at the Miyazaki Yearling Training Farm ( $31^{\circ} 90^{\prime} \mathrm{N}, 139^{\circ} 42^{\prime} \mathrm{E}$, Miyazaki) and 24 horses (12 colts and 12 fillies) being reared at the Hidaka Training and Research Center ( $42^{\circ} 17^{\prime} \mathrm{N}, 142^{\circ} 72^{\prime} \mathrm{E}$, Hidaka) of the JRA; these two locations are in regions with warm and cold climates, respectively. The horses were at the farms from the end of August at one year old to April at two years old. A four-month EP treatment was performed from December 20 at one year old to April 10 at two years old in 12 horses (6 colts and 6 fillies) reared in Miyazaki and 12 horses ( 6 colts and 6 fillies) reared in Hidaka. The remaining 12 horses (6 colts and 6 fillies) in Miyazaki and 12 horses ( 6 colts and 6 fillies) in Hidaka were reared under natural light alone, respectively, as control groups. For hair coat condition analysis, 206 Thoroughbreds reared in Miyazaki (12 colts and 49 fillies in the EP treatment group and 12 colts and 12 fillies in the control group) and Hidaka (48 colts and 49 fillies in the EP treatment group and 12 colts and 12 fillies in the control group) were used. The ages of the animals at the time of experiment initiation were between 19 and 22 months old. All procedures were carried out in accordance with the guidelines established by Hidaka Training and
Research Center for care and use of horses in research.

\section{EP treatment}

A 100-watt white light bulb was set in the ceilings of stalls $(3.6 \times 3.6 \mathrm{~m})$, and lighting conditions of 14.5-hr light and 9.5-hr dark were determined for the EP treatment. The intensity of illumination under the bulb at the height of the horse's face was approximately 100 lux.

\section{Collection of blood}

Blood was collected from the jugular vein into a heparinized vacutainer $(10 \mathrm{ml})$ between 0900 and $1200 \mathrm{hr}$ once a month from horses reared in Miyazaki and Hidaka between November at one year old and April at two years old. Plasma was harvested and stored at $-20^{\circ} \mathrm{C}$ until assayed.

\section{Growth parameters}

For the growth parameters, the body weight, height at withers, and girth and cannon circumferences were measured in December at one year old and April at two years old. To compare the growth rate of horses during the four months from December at one year old to April at two years old, the percent increments in the four parameters were calculated (values of April/values of December $\times 100$ ).

\section{Estimation of the condition of the hair coat}

The condition of the hair coat was evaluated in March at two years old. Three examiners randomly evaluated hair using a 3-point scoring method: "excellent", "normal", and "poor" were scored as 3,2, and 1, respectively, and the mean scores were compared.

\section{Hormone assays}

The plasma concentrations of prolactin, luteinizing hormone ( $\mathrm{LH})$, and follicle-stimulating hormone (FSH) were determined by homologous double-antibody equine radioimmunoassay (RIA) methods as described previously [17]. Plasma concentrations of prolactin were measured using an anti-equine prolactin serum (AFP-261987) and purified equine prolactin (AFP-8794B) for radioiodination and for the reference standard. Plasma concentrations of LH were measured using an anti-equine LH serum (AFP2405080) and purified equine LH (AFP-2405080) for radioiodination and for the reference standard (AFP-50130A). Plasma concentrations of FSH were measured using an anti-equine FSH serum (AFP-2062096) and purified equine FSH (AFP-5022B) for radioiodination and for the reference standard. Intra- and inter-assay coefficients of variation were $7.1 \%$ and $9.8 \%$ for prolactin, $12.6 \%$ and $15.1 \%$ for $\mathrm{LH}$, and $4.9 \%$ and $12.2 \%$ for $\mathrm{FSH}$, respectively.

The plasma concentrations of insulin-like growth factor (IGF-1) were measured by RIA as previously described [14] 
using anti-sera against human IGF-1 (AP 4892898) and purified human IGF-1 (Lot \#090701) for radioiodination and for the reference standard. The intra- and inter-assay coefficients of variation were $2.7 \%$ and $14.8 \%$, respectively.

The concentrations of progesterone, testosterone, and estradiol-17 $\beta$ were determined by double-antibody RIA systems using ${ }^{125}$ I-labeled radioligands as previously described [57]. Anti-sera against progesterone (GDN 337) [26], testosterone (GDN 250) [25], and estradiol-17 $\beta$ (GDN 244) [41] were used in each RIA. The intra- and inter-assay coefficients of variation were $7.3 \%$ and $14.3 \%$ for progesterone, $6.3 \%$ and $7.2 \%$ for testosterone, and $6.7 \%$ and $17.8 \%$ for estradiol- $17 \beta$, respectively.

\section{Determination of ovulation}

The day seven days prior to the day when the plasma concentration of progesterone initially reached $1 \mathrm{ng} / \mathrm{ml}$ or higher was regarded as the initial ovulation day $[44,46]$.

\section{Statistical analysis}

All results are expressed as the mean \pm standard error of the mean (SEM). Statistical comparisons between the two groups were performed by Student's $t$-test when uniformity of variance was confirmed by the $F$-test. When the variance was not uniform, the unpaired $t$-test with Welch's correction was used. Differences among times of sampling were evaluated by two-way repeated measure analysis of variance (ANOVA) with post hoc testing by Bonferroni post test. $P<0.05$ was considered to be statistically significant.

\section{Results}

\section{Colts reared in Miyazaki}

The mean rates of increase over the 4 months in the 4 parameters for the colts reared in Miyazaki are shown in Fig. 1a. No significant difference was noted in the mean rates of increase over the 4 months for body weight, height at withers, girth, or cannon circumference between the EP treatment and control groups.

Changes in the plasma concentrations of prolactin, $\mathrm{LH}$, FSH, IGF-1, testosterone, and estradiol-17 $\beta$ of colts reared in Miyazaki from November to April in the EP treatment and control groups are shown in Fig. 2. In the EP treatment group, the plasma concentration of prolactin began to increase in December and abruptly increased in February, and the level was significantly higher in the EP treatment group than the control group from December to April (Fig. $2 \mathrm{a})$. The basal plasma concentration of LH (0.16-0.54 ng/ $\mathrm{m} l$ ) was maintained from November to April in the EP treatment group, but it rose from January onward in the control group; however, it was not significantly different between the two groups (Fig. 2b). The plasma concentrations of

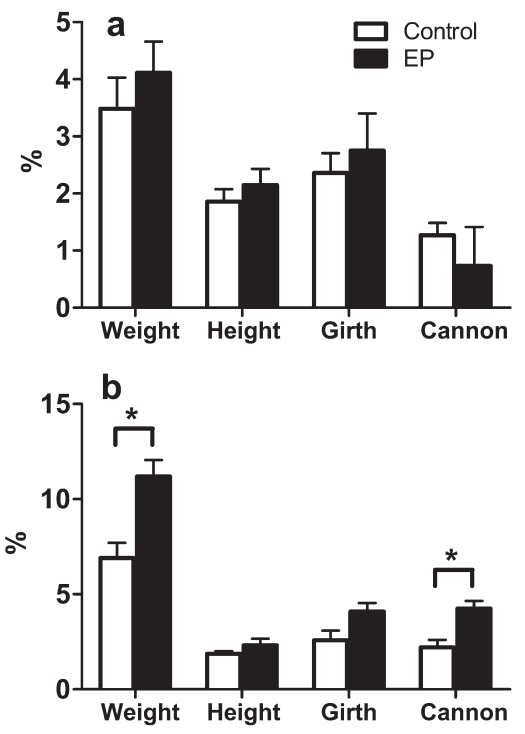

Fig. 1. Comparison of the mean rates of increase of body weight, height at withers, and girth and cannon circumference between the control group ( $\square$ ) and extended photoperiod (EP) treatment group ( $\square$ ) over the four months from December at one year old to April at two years old in Thoroughbred colts (a) and fillies (b) reared at the Miyazaki Yearling Training Farm of the Japan Racing Association. Results are expressed as means \pm SEM. *Significant difference between the two groups in each parameter at $P<0.05$.

FSH (Fig. 2c) and testosterone (Fig. 2e) were significantly higher in the control group than in the EP treatment group in April, but no significant difference was noted between the two groups in the other months. The plasma concentration of IGF-1 was not significantly different between the two groups (Fig. 2d). The plasma concentration of estradiol-17 $\beta$ was higher in the control group than the EP treatment group from January to April, but the difference was not significant (Fig. 2f).

\section{Fillies reared in Miyazaki}

The mean rates of increase over the 4 months in the 4 parameters for fillies reared in Miyazaki are shown in Fig. 1b. The rates of increases in body weight and cannon circumference over the 4-month period were significantly higher in the EP treatment group than the control group, and the rates for all 4 items were significantly higher in the EP treatment group than the control group in February (data not shown).

Changes in the plasma concentrations of prolactin, LH, FSH, IGF-1, progesterone, and estradiol-17 $\beta$ for fillies reared in Miyazaki from November to April in the EP treatment and control groups are shown in Fig. 3. The plasma concentration of prolactin was significantly high in 

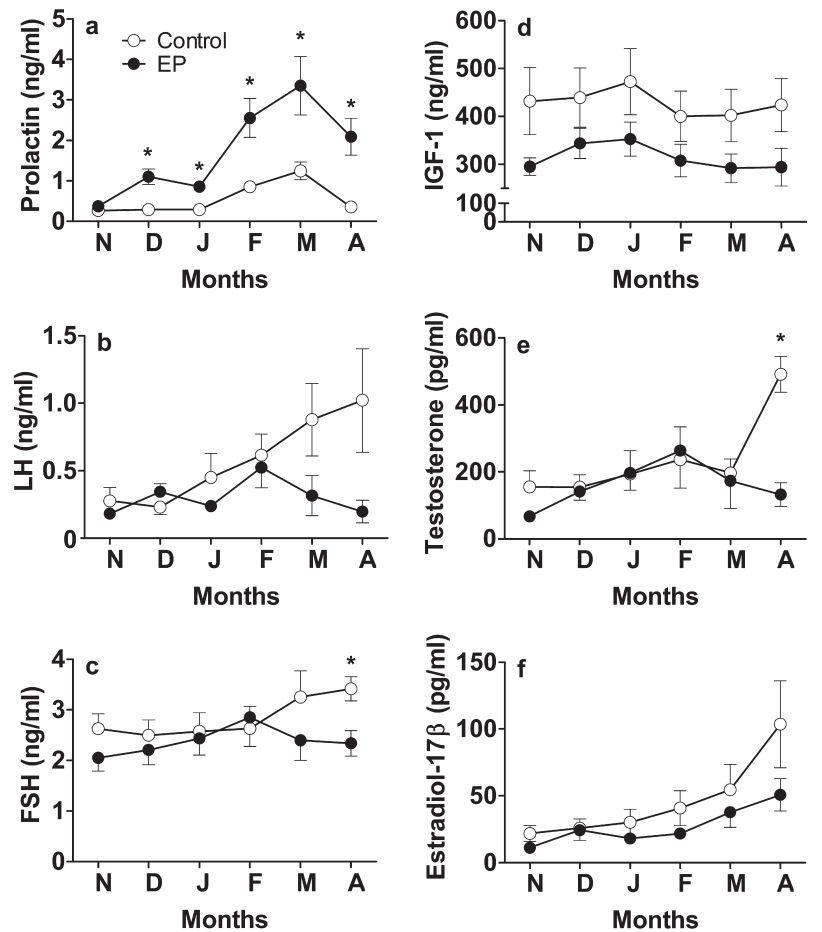

Fig. 2. Changes in the plasma concentrations of prolactin (a), LH (b), FSH (c), IGF-1 (d), testosterone (e), and estradiol-17 $\beta$ (f) in Thoroughbred colts in the extended photoperiod (EP) treatment group $(\bullet)$ and the control group (०) from November at one year old to April at two years old reared at the Miyazaki Yearling Training Farm of the Japan Racing Association. Results are expressed as means \pm SEM. Months are indicated by their initial letter. *Significant difference between the two groups at the same sampling point at $P<0.05$.

the EP treatment group compared with the control group in January and February, but it became significantly higher in the control group than the EP treatment group in April (Fig. 3a). The plasma concentration of LH did not change until April in the control group, but it rose in January in the EP treatment group. After February, it was higher in the EP treatment group, but the differences between the two groups were not significant (Fig. 3b). The plasma concentration of FSH was significantly higher in the EP treatment group than the control group in March and April (Fig. 3c). No significant difference was noted in the plasma concentrations of IGF-1 between the two groups (Fig. 3d). The plasma concentration of progesterone was low from November to January in both groups. It was significantly high in the control group as compared with the EP treatment group. The plasma concentration of progesterone rose in February in some fillies in the EP treatment group, whereas the level did not change until April in the control group. After February, no significant difference was noted
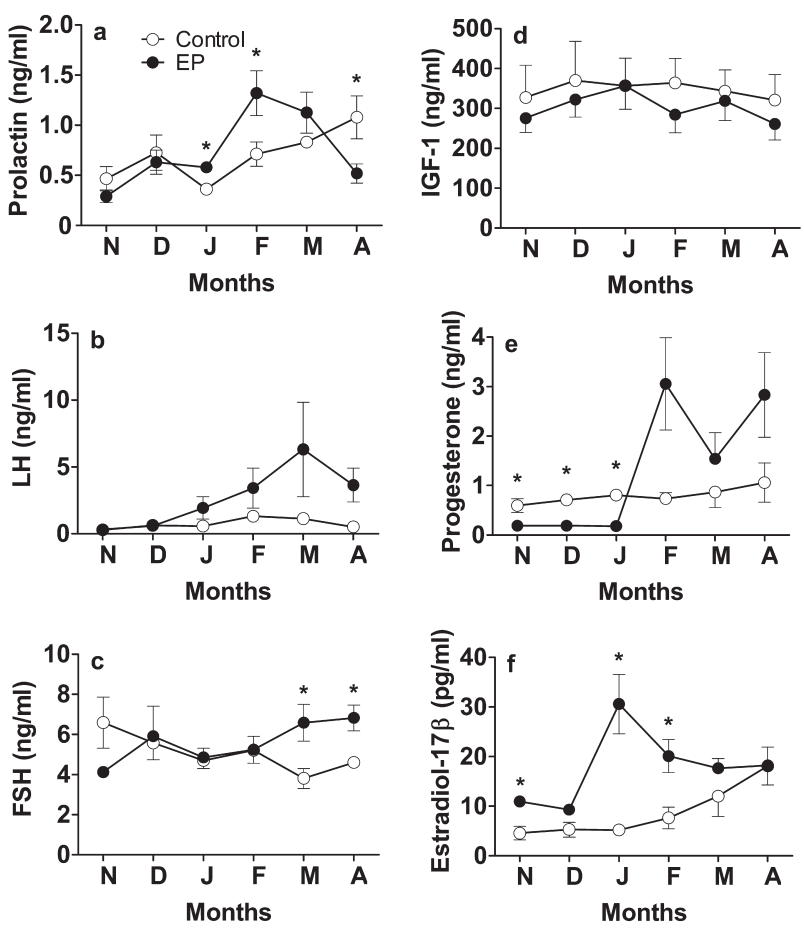

Fig. 3. Changes in the plasma concentrations of prolactin (a), LH (b), FSH (c), IGF-1 (d), progesterone (e), and estradiol-17 $\beta$ (f) in Thoroughbred fillies in the extended photoperiod (EP) treatment group $(\bullet)$ and the control group $(\circ)$ from November at one year old to April at two years old reared at the Miyazaki Yearling Training Farm of the Japan Racing Association. Results are expressed as means \pm SEM. Months are indicated by their initial letter. *Significant difference between the two groups at the same sampling point at $P<0.05$.

because it rose to a high level in many fillies in the EP treatment group and there was increased variation of the mean (Figs. 3e and 4). The plasma concentration of estradiol-17 $\beta$ gradually rose from February in the control group, but it abruptly rose in January in the EP treatment group and it was significantly higher in the EP treatment group than the control group in November, January, and February (Fig. 3f). The initial ovulation occurred before April in 2 (33.3\%) and $5(83.3 \%)$ of 6 fillies in the control and EP treatment groups, respectively (Fig. 4).

\section{Colts reared in Hidaka}

The mean rates of increase over the 4 months in the 4 parameters for colts reared in Hidaka are shown in Fig. 5a. The rates of increases in body weight and height at withers were significantly higher in the EP treatment group than the control group (Fig. 5a).

Changes in the plasma concentrations of prolactin, LH, FSH, IGF-1, testosterone, and estradiol-17 $\beta$ of colts 

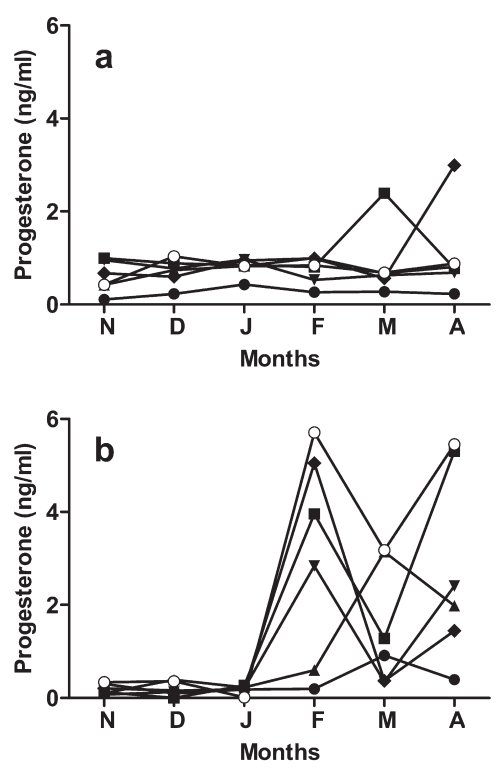

Fig. 4. Changes in the plasma concentrations of progesterone from November at one year old to April at two years old in individual Thoroughbred fillies in the control (a) and extended photoperiod (EP) treatment groups (b) reared at the Miyazaki Yearling Training Farm of the Japan Racing Association. Months are indicated by their initial letter.

reared in Hidaka from November to April in the EP treatment and control groups are shown in Fig. 6. The plasma concentration of prolactin rose from February to April in the control group, but it rose from January in the EP treatment group, and the level was significantly higher in the EP treatment group in January and February (Fig. 6a). The plasma concentration of LH (Fig. 6b) was maintained at the basal level until April in the control group, but it rose from January to April in the EP treatment group, and the level was not significantly different compared with that of the control group. No significant difference was noted in the plasma concentrations of FSH (Fig. 6c) and IGF-1 (Fig. $6 \mathrm{~d})$ between the two groups. The plasma concentration of testosterone rose in March in the control group and from January to April in the EP treatment group, but no significant difference was noted between the two groups because of marked variation among individuals in the EP treatment group (Fig. 6e). The plasma concentration of estradiol-17 $\beta$ rose from February to April in the control group, but it rose from January onward in the EP treatment group and was significantly higher than that in the control group in March (Fig. 6f).

\section{Fillies reared in Hidaka}

The mean rates of increase over the 4 months in the 4 parameters for fillies reared in Hidaka are shown in Fig. 5 b.
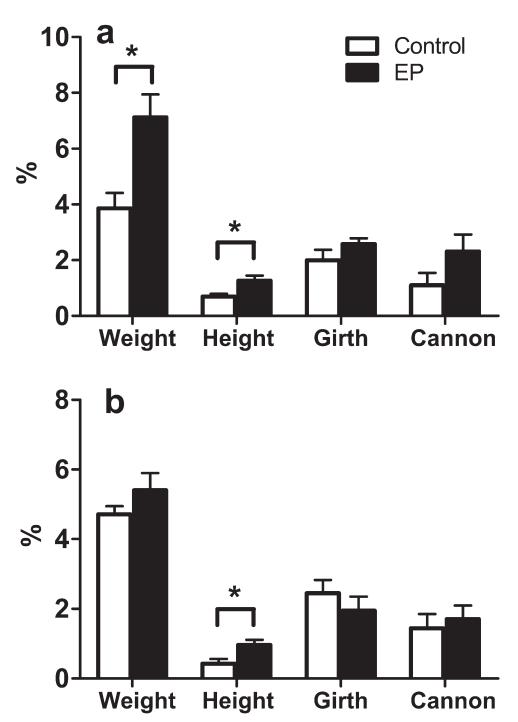

Fig. 5. Comparison of the mean rates of increase of body weight, height at withers, girth, and cannon circumference between the control group ( $\square$ ) and extended photoperiod (EP) treatment group (घ) over the four months from December at one year old to April at two years old in Thoroughbred colts (a) and fillies (b) reared at the Hidaka Training and Research Center of the Japan Racing Association. Results are expressed as means \pm SEM. *Significant difference between the two groups in each parameter at $P<0.05$.

The rate of increase in height at withers was significantly higher in the EP treatment group than the control group (Fig. 5b).

Changes in the plasma concentrations of prolactin, $\mathrm{LH}$, FSH, IGF-1, progesterone, and estradiol-17 $\beta$ for fillies reared in Hidaka from November to April in the EP treatment and control groups are shown in Fig. 7. The plasma concentration of prolactin rose in March in the control group, whereas it rose in January in the EP treatment group, and the level was significantly higher in the EP treatment group than the control group in January and February (Fig. 7a). The plasma concentration of LH (Fig. 7b) rose in April in the control group, but it rose in February in the EP treatment group. No significant difference was noted in the level between the two groups because variations among individuals were marked in the EP treatment group. The plasma concentration of FSH rose slightly in both the EP treatment and control groups in December, and the level did not change until April in the control group; however, it rose from February in the EP treatment group, and the level was significantly higher in the EP treatment group than in the control group in March (Fig. 7c). No significant difference was noted in the plasma concentrations of IGF-1 between the two groups (Fig. 7d). 

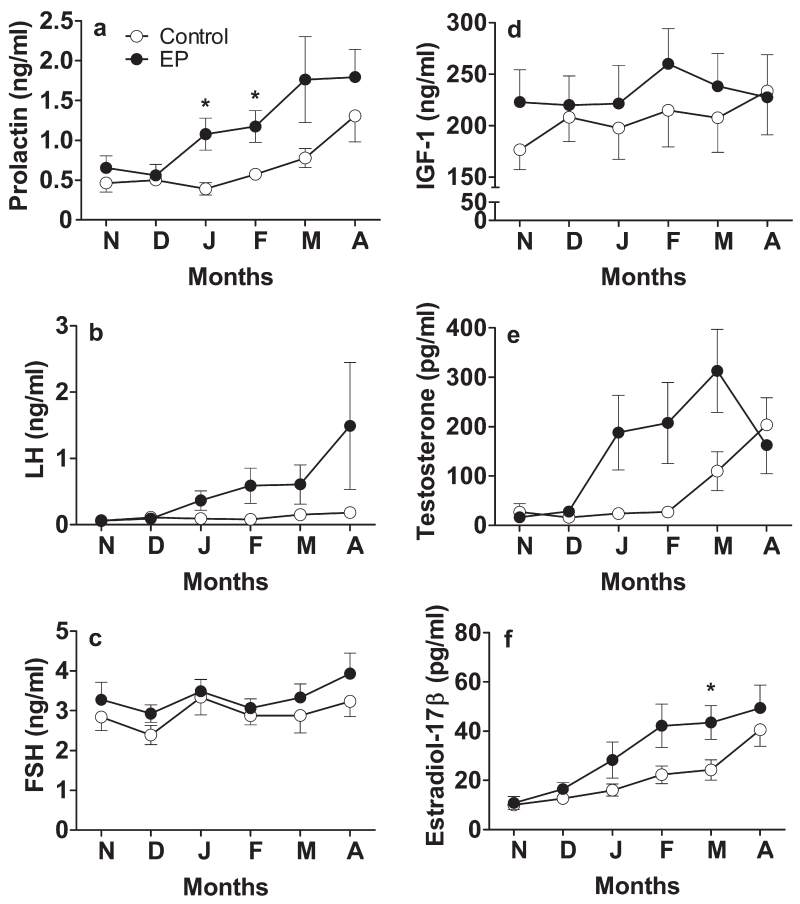

Fig. 6. Changes in the plasma concentrations of prolactin (a), LH (b), FSH (c), IGF-1 (d), testosterone (e), and estradiol-17 $\beta$ (f) in Thoroughbred colts in the extended photoperiod (EP) treatment group (•) and the control group ( $\odot$ ) from November at one year old to April at two years old reared at the Hidaka Training and Research Center of the Japan Racing Association. Results are expressed as means \pm SEM. Months are indicated by their initial letter. *Significant difference between the two groups at the same sampling point at $P<0.05$.

The plasma concentration of progesterone rose in April in the control group, whereas it rose in February in the EP treatment group, but no significant difference was noted between the two groups because of large variation among individuals in the EP treatment group (Figs. 7e and 8 b). The plasma concentration of estradiol- $17 \beta$ rose in March in the control group and in January in the EP treatment group, but no significant difference was noted between the two groups (Fig. 7f). Ovulation occurred before April only in 2 $(33.3 \%)$ of the 6 fillies in the control group but occurred in all $6(100 \%)$ of the fillies in the EP treatment group (Fig. 8).

\section{Changes in molting of winter coats}

Representative photographs taken at the end of March at two years old ( 3 months after EP treatment initiation) of colts and fillies in the control and EP treatment groups in Miyazaki and Hidaka are shown in Fig. 9, and graphs of the scores of the four groups are shown in Fig. 10. The representative photographs show that winter coats were still maintained in the control group reared in Miyazaki (colt,
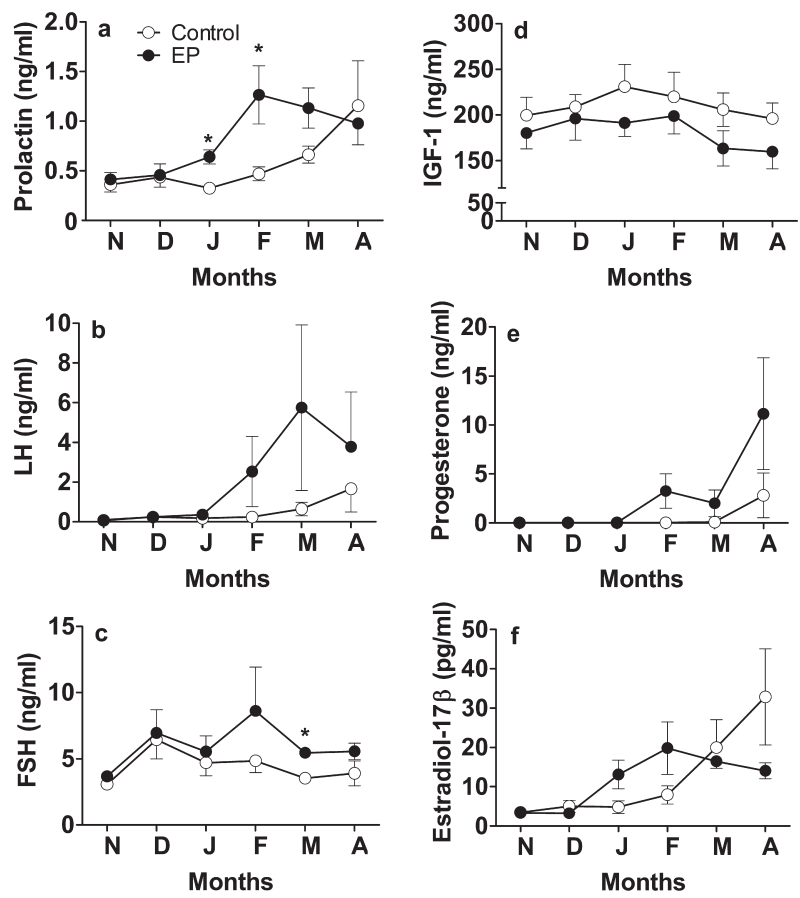

Fig. 7. Changes in the plasma concentrations of prolactin (a), LH (b), FSH (c), IGF-1 (d), progesterone (e), and estradiol-17 $\beta$ (f) in Thoroughbred fillies in the extended photoperiod (EP) treatment group $(\bullet)$ and the control group $(\circ)$ from November at one year old to April at two years old reared at the Hidaka Training and Research Center of the Japan Racing Association. Results are expressed as means \pm SEM. Months are indicated by their initial letter. *Significant difference between the two groups at the same sampling point at $P<0.05$.

Fig. 9A; filly, Fig. 9C) and in Hidaka (colt, Fig. 9E; filly, Fig. 9G), whereas the molting of winter coats was advanced in colts (Miyazaki, Fig. 9B; Hidaka, Fig. 9F) and fillies (Miyazaki, Fig. 9D; Hidaka, Fig. 9H) in the EP treatment group at the end of March. The score was significantly higher in the EP treatment group than the control groups in colts (Fig. 10A) and fillies (Fig. 10B) in Miyazaki and colts (Fig. 10C) and fillies (Fig. 10D) in Hidaka.

\section{Discussion}

In the present study, the EP treatment was applied to yearlings reared in Miyazaki for the first time, and the effects on growth, gonadal function, and molting of winter coats were compared with those in yearlings reared in Hidaka. It was clarified that the effects of the EP treatment on yearlings were different between Miyazaki and Hidaka, southern and northern areas of Japan, respectively. Promotion of growth and early activation of gonadal function were noted in both colts and fillies in Hidaka. On the other hand, in Miyazaki, 

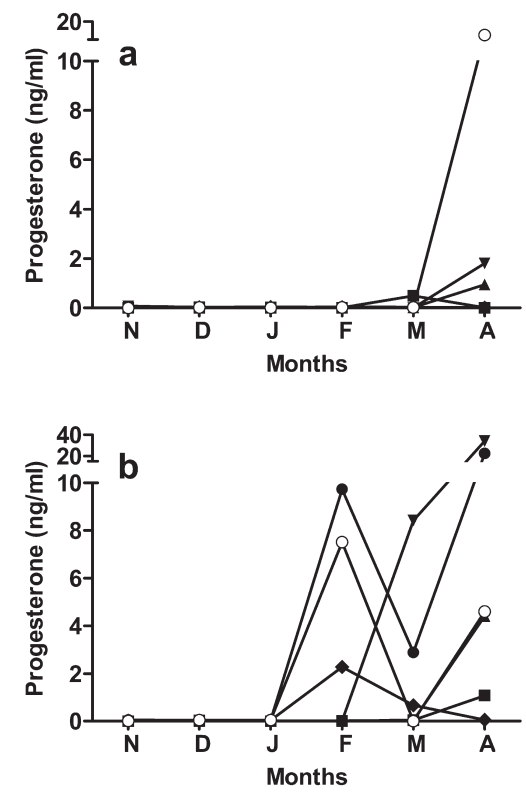

Fig. 8. Changes in the plasma concentrations of progesterone from November at one year old to April at two years old in individual Thoroughbred fillies in the control (a) and extended photoperiod (EP) treatment groups (b) reared at the Hidaka Training and Research Center of the Japan Racing Association. Months are indicated by their initial letter.

these were observed in fillies, but no effect of the EP treatment was noted in colts, showing a difference in the effect of the EP treatment between Miyazaki and Hidaka.

Regarding growth, body weight and height at withers in colts and height at withers in fillies were greater in yearlings reared under the EP treatment than in those reared under natural light in Hidaka. In fillies reared in Miyazaki, body weight and cannon circumference were greater in the 4-month EP treatment group than the control group. In addition, the rate of increase rose significantly in February ( 2 months after EP treatment initiation) in all 4 items (body weight, height at withers, girth, and cannon circumference; data not shown). Regarding gonadal development, the EP treatment promoted gonadal function in colts and fillies reared in Hidaka and fillies in Miyazaki. An increase in testicular hormone secretion was noted in colts, and promotion of follicular growth and advancement of ovulation were noted in fillies, clarifying that EP treatment promotes gonadal function in yearling fillies in a manner similar to broodmares [7, 23, 53]. No effect of the EP treatment on growth and gonadal function was noted in colts reared in Miyazaki, and the reason for this is unclear at this point. In our previous observations for comparing the growth of yearlings reared under natural light between Miyazaki and Hidaka, growth was superior in both colts and fillies reared in Miyazaki [45]. Since there is a limit to growth, the light stimulation-induced promotion of growth may not have been perceivable for body weight, height at withers, girth, or cannon circumference in colts reared in Miyazaki. However, the prolactin secretion level markedly increased in colts reared in Miyazaki, suggesting that increased prolactin acts on some biological functions in colts and fillies reared in Miyazaki and Hidaka. Indeed, the present study clearly showed that the molting of winter coats was as advanced in colts of the EP treatment group reared in Miyazaki as in fillies reared in Miyazaki and colts and fillies reared in Hidaka. The effects of the EP treatment on colts reared in Miyazaki deserves further investigation.

Regarding endocrine changes, prolactin secretion was promoted as a common phenomenon in both colts and fillies reared in Miyazaki and Hidaka. The effects of the EP treatment on endocrine changes in colts and fillies reared in Hidaka were consistent with those reported in our previous paper $[42,50]$. Prolactin secretion is promoted with prolonging of the photoperiod, and it has diverse actions [5, 6, 12, 16, 17, 24, 27]. In addition, its promotion of coat molting and nest-building has been reported [18-20, 58, 59]. Prolactin receptors were expressed on the epiphyseal growth plate, and prolactin extended the tibia in lactating rats [54]. Prolactin has also been reported to promote calcium absorption from the intestine $[9,10$, 55]. Furthermore, it promotes glucocorticoid secretion by adrenocortical cells [32-36], potentiates the immune function, and prevents gastric ulcer [2], and it has recently attracted attention as an anti-stress hormone [56]. Regarding the gonads, previous papers suggested that prolactin plays important physiological roles in ovarian function in mares in a systemic and local fashion [37, 38, 51]. Furthermore, the presence of prolactin and dopamine receptors was demonstrated in ovarian tissues of mares [37-39]. Prolactin upregulates its receptor and maintains the $\mathrm{LH}$ receptor in luteal cells of the mink [21]. Prolactin also has physiological roles in male reproduction in mammals, such as in steroidogenesis, gametogenesis, or sexual behavior, in many mammals [3]. An increase in circulating prolactin in the long-day period in stallions and geldings has also been reported [16]. The expression of prolactin receptor has been reported in the testes and various male accessory glands of human, bear, and dear [28-31], indicating that these organs might be targets of prolactin in male reproductive organs. Previous studies have also demonstrated that expression of the testicular prolactin receptor increased during testicular recrudescence in the breeding season of the bear or golden hamster [4, 30, 40].

Secretion of IGF-1 is induced by growth hormone, is mainly secreted by the liver, and promotes body growth [15]. The measurement of IGF-1 gives the clue of status 

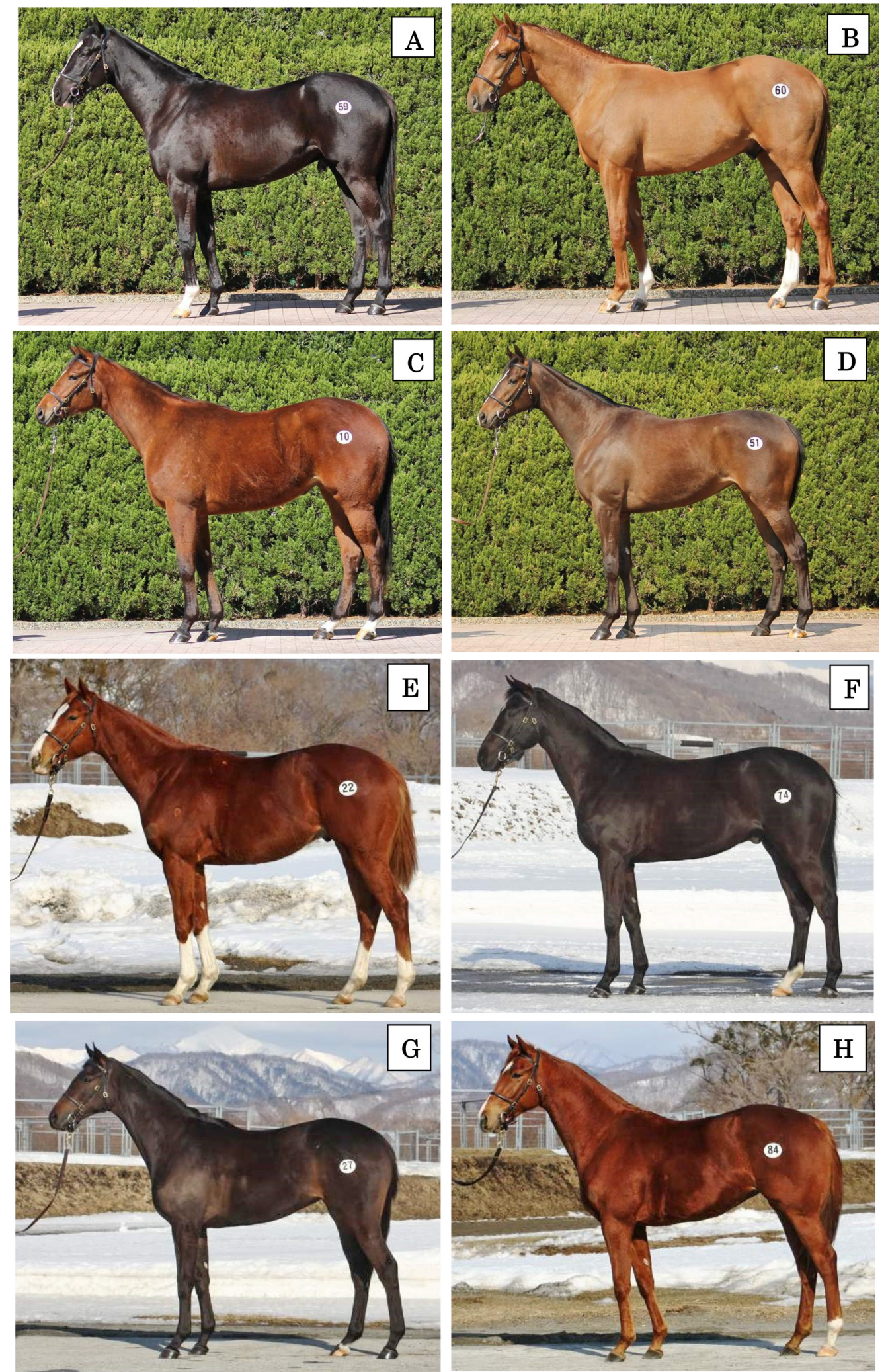

Fig. 9. Comparison of the hair coat conditions of representative colts (control, A; extended photoperiod (EP) treatment, B) and fillies (control, C; EP treatment, D) reared at the Miyazaki Yearling Training Farm and of those of colts (control, E; EP treatment, F) and fillies (control, G; EP treatment, H) reared at the Hidaka Training and Research Center of the Japan Racing Association in March at two years old. 

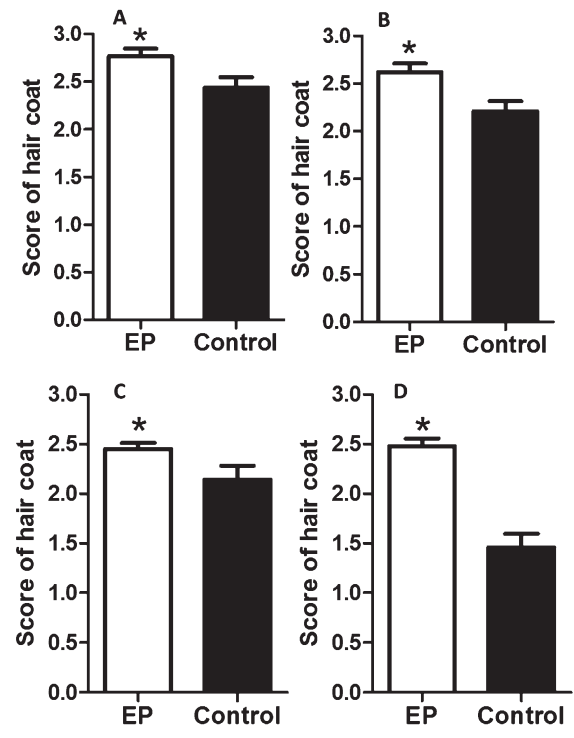

Fig. 10. Comparison of scores for hair coat condition between the extended photoperiod (EP) treatment group ( $\square$ ) and control group (घ) for horses reared at the Miyazaki Yearling Training Farm (colts, A; fillies, B) and Hidaka Training and Research Center of the Japan Racing Association (colts, C; fillies, D). Results are expressed as means \pm SEM. *Significant difference at $P<0.05$.

of the somatotropic axis as it has longer half-life with no obvious diurnal rhythm [8]. Localization of IGF-1 and its receptor has been demonstrated in equine testes [60], but long-day stimulation applied by the EP treatment did not change the secretion level in horses reared in either Miyazaki or Hidaka in the present study.

The EP treatment increased the secretion of two gonadotropic hormones ( $\mathrm{LH}$ and FSH) from the pituitary in colts and fillies reared in Hidaka and fillies reared in Miyazaki. Testosterone and estradiol-17 $\beta$ secretions from the testis increased in colts reared in Hidaka, and estradiol-17 $\beta$ and progesterone secretions from the ovary increased in fillies reared in Hidaka and Miyazaki. In mares, estradiol-17 $\beta$ is secreted by mature follicles, and progesterone is secreted by the corpus luteum $[44,46]$, suggesting that secretion of these hormones was promoted due to EP treatment-induced promotion of LH and FSH secretion from the pituitary in fillies in the present study. In colts, Leydig cells in the testis may have been stimulated and secreted testosterone and estradiol-17 $\beta$, promoting spermatogenesis. In fillies, follicular growth into a mature follicle may have been stimulated and resulted in early ovulation. Based on the results of hormones measurement, gonadotropic hormone secretion from the pituitary increased from the end of January, about one month after EP treatment initiation, in both colts and fillies, clarifying that about one month is necessary to achieve an effect of EP treatment on the hypothalamus and pituitary axis in yearlings. Estrus and ovulation start after April at two years old in many fillies reared under natural light. Therefore, initiation of EP treatment in December advances ovulation by about two months in fillies in a manner similar to broodmares.

In the stallion, testosterone and estradiol-17 $\beta$ are secreted by Leydig cells in the testis [47-49]. Testosterone promotes the growth and function of the male accessory reproductive glands and enhances spermatogenesis. It is also known to increase fat catabolism and inhibit the accumulation of triglycerides, reducing body fat accumulation [1]. Testosterone also has a potent protein-assimilating action and increases muscle mass [22]. Furthermore, it directly acts on bone or is converted to estradiol-17 $\beta$ by aromatase, and it promotes osteogenesis $[11,44,52]$. Estradiol- $17 \beta$ is secreted by granulosa cells of the mature antral follicle in mares $[44,46]$. It induces estrus and preparation for fertilization and implantation by promoting endometrial growth, development of the uterine gland, and uterine and vaginal mucous secretion. Its action on bone is also known, and it promotes bone maturation and increases the bone mineral density [43]. Estradiol-17 $\beta$ also enhances fat metabolism and reduces body fat accumulation [13].

In summary, it was clarified that the growth of Thoroughbred yearlings reared under natural light in Japanese climates is superior in Miyazaki (southern area) compared with Hidaka (northern area) [45]. However, it may be possible to promote growth in Hidaka so that it is close to that in Miyazaki by extending the hours of sunlight by EP treatment. It is necessary to closely investigate the influences of EP treatment on muscles, fat, and cardiopulmonary function in the rearing of yearlings subjected to EP treatment.

\section{Acknowledgments}

We are grateful to the National Hormone and Pituitary Program, NIDDK, NIH (Torrance, CA, U.S.A.), and Dr. A. F. Parlow for providing prolactin, $\mathrm{LH}, \mathrm{FSH}$, and IGF-1 kits and to Dr. G. D. Niswender, Animal Reproduction and Biotechnology Laboratory, Colorado State University (Fort Collins, CO, U.S.A.), for providing antisera to progesterone (GDN 337), testosterone (GDN 250), and estradiol-17 $\beta$ (GDN 244). We thank Dr. Kazuki Fujii, Laboratory of Veterinary Physiology, Cooperative Department of Veterinary Medicine, Faculty of Agriculture, Tokyo University of Agriculture and Technology (Fuchu, Tokyo, Japan), for his help in preparation of the manuscript. 


\section{References}

1. Arslanian, S., and Suprasongsin, C. 1997. Testosterone treatment in adolescents with delayed puberty: changes in body composition, protein, fat, and glucose metabolism. $J$. Clin. Endocrinol. Metab. 82: 3213-3220. [Medline]

2. Asai, S., Ohta, R., Fujikawa, T., Sakai, R.R., Shirota, M., Ogata, M., Watanabe, G., and Taya, K. 2006. Gastric ulceration and expression of prolactin receptor in the brain in Hatano high- and low-avoidance rats. Endocrine 30: 161-166. [Medline] [CrossRef]

3. Bartke, A. 2004. Prolactin in the male: 25 years later. $J$. Androl. 25: 661-666. [Medline]

4. Bartke, A., Klemcke, H.G., Amador, A., and Van Sickle, M. 1982. Photoperiod and regulation of gonadotropin receptors. Ann. N. Y. Acad. Sci. 383: 122-134. [Medline] [CrossRef]

5. Ben-Jonathan, N., LaPensee, C.R., and LaPensee, E.W. 2008. What can we learn from rodents about prolactin in humans? Endocr. Rev. 29: 1-41. [Medline] [CrossRef]

6. Bernichtein, S., Touraine, P., and Goffin, V. 2010. New concepts in prolactin biology. J. Endocrinol. 206: 1-11. [Medline] [CrossRef]

7. Burkhardt, J. 1947. Transition from anestrus in the mare and effects of artificial lighting. J. Agric. Sci. 37: 64-68. [CrossRef]

8. Champion, Z.J., Breier, B.H., Ewen, W.E., Tobin, T.T., and Casey, P.J. 2002. Blood plasma concentrations of insulinlike growth factor-I (IGF-I) in resting standardbred horses. Vet. J. 163: 45-50. [Medline] [CrossRef]

9. Charoenphandhu, N., Nakkrasae, L.I., Kraidith, K., Teerapornpuntakit, J., Thongchote, K., Thongon, N., and Krishnamra, N. 2009. Two-step stimulation of intestinal $\mathrm{Ca}^{2+}$ absorption during lactation by long-term prolactin exposure and suckling-induced prolactin surge. Am. J. Physiol. Endocrinol. Metab. 297: E609-E619. [Medline] [CrossRef]

10. Charoenphandhu, N., Wongdee, K., and Krishnamra, N. 2010. Is prolactin the cardinal calciotropic maternal hormone? Trends Endocrinol. Metab. 21: 395-401. [Medline] [CrossRef]

11. Clarke, B.L., and Khosla, S. 2009. Androgens and bone. Steroids 74: 296-305. [Medline] [CrossRef]

12. Curlewis, J.D. 1992. Seasonal prolactin secretion and its role in seasonal reproduction: a review. Reprod. Fertil. Dev. 4: 1-23. [Medline] [CrossRef]

13. D'Eon, T.M., Sharoff, C., Chipkin, S.R., Grow, D., Ruby, B.C., and Braun, B. 2002. Regulation of exercise carbohydrate metabolism by estrogen and progesterone in women. Am. J. Physiol. Endocrinol. Metab. 283: E1046-E1055. [Medline] [CrossRef]

14. Derar, R., Haramaki, S., Hoque, S., Hashizume, T., Osawa, T., Taya, K., Watanabe, G., and Miyake, Y. 2006. Immunoreactive Insulin-like growth factor in plasma during pre-and post-partum periods of thoroughbred mares from which the newborn were removed: its pattern, physiological function and relation to other hormones. J. Equine Sci. 17: 75-79. [CrossRef]

15. Le Roith, D., Bondy, C., Yakar, S., Liu, J.L., and Butler, A. 2001. The somatomedin hypothesis: 2001. Endocr. Rev. 22: 53-74. [Medline] [CrossRef]

16. Dhakal, P., Tsunoda, N., Nakai, R., Kitaura, T., Harada, T., Ito, M., Nagaoka, K., Toishi, Y., Taniyama, H., Watanabe, G., and Taya, K. 2011. Annual changes in day-length, temperature, and circulating reproductive hormones in Thoroughbred stallions and gelgings. J. Equine Sci. 22: 29-36. [Medline] [CrossRef]

17. Dhakal, P., Hirama, A., Nambo, Y., Harada, T., Sato, F., Nagaoka, K., Watanabe, G., and Taya, K. 2012. Circulating pituitary and gonadal hormones in spring-born Thoroughbred fillies and colts from birth to puberty. J. Reprod. Dev. 58: 522-530. [Medline] [CrossRef]

18. Donadeu, F.X., and Thompson, D.L. Jr. 2002. Administration of sulpiride to anovulatory mares in winter: effects on prolactin and gonadotropin concentrations, ovarian activity, ovulation and hair shedding. Theriogenology 57: 963-976. [Medline] [CrossRef]

19. Thompson, D.L. Jr., and DePew, C.L. 1997. Prolactin, gonadotropin, and hair shedding responses to daily sulpiride administration in geldings in winter. J. Anim. Sci. 75: 1087-1091. [Medline]

20. Thompson, D.L. Jr., Hoffman, R., and DePew, C.L. 1997. Prolactin administration to seasonally anestrous mares: reproductive, metabolic, and hair-shedding responses. $J$. Anim. Sci. 75: 1092-1099. [Medline]

21. Douglas, D.A., Houde, A., Song, J.H., Farookhi, R., Concannon, P.W., and Murphy, B.D. 1998. Luteotropic hormone receptors in the ovary of the mink (Mustela vison) during delayed implantation and early-postimplantation gestation. Biol. Reprod. 59: 571-578. [Medline] [CrossRef]

22. Evans, N.A. 2004. Current concepts in anabolic-androgenic steroids. Am. J. Sports Med. 32: 534-542. [Medline] [CrossRef]

23. Freedman, L.J., Garcia, M.C., and Ginther, O.J. 1979. Influence of photoperiod and ovaries on seasonal reproductive activity in mares. Biol. Reprod. 20: 567-574. [Medline] [CrossRef]

24. Freeman, M.E., Kanyicska, B., Lerant, A., and Nagy, G. 2000. Prolactin: structure, function, and regulation of secretion. Physiol. Rev. 80: 1523-1631. [Medline]

25. Gay, V.L., and Kerlan, J.T. 1978. Serum LH and FSH following passive immunization against circulating testosterone in the intact male rat and in orchidectomized rats bearing subcutaneous silastic implants of testosterone. Arch. Androl. 1: 257-266. [Medline] [CrossRef]

26. Gibori, G., Antczak, E., and Rothchild, I. 1977. The role of estrogen in the regulation of luteal progesterone secretion in the rat after day 12 of pregnancy. Endocrinology 100: 
1483-1495. [Medline] [CrossRef]

27. Goffin, V., Binart, N., Touraine, P., and Kelly, P.A. 2002. Prolactin: the new biology of an old hormone. Annu. Rev. Physiol. 64: 47-67. [Medline] [CrossRef]

28. Goffin, V., Hoang, D.T., Bogorad, R.L., and Nevalainen, M.T. 2011. Prolactin regulation of the prostate gland: a female player in a male game. Nat. Rev. Urol. 8: 597-607. [Medline] [CrossRef]

29. Hair, W.M., Gubbay, O., Jabbour, H.N., and Lincoln, G.A. 2002. Prolactin receptor expression in human testis and accessory tissues: localization and function. Mol. Hum. Reprod. 8: 606-611. [Medline] [CrossRef]

30. Howell-Skalla, L.A., Bunick, D., Nelson, R.A., and Bahr, J.M. 2000. Testicular recrudescence in the male black bear (Ursus americanus): changes in testicular luteinizing hormone-, follicle-stimulating hormone-, and prolactinreceptor ribonucleic acid abundance and dependency on prolactin. Biol. Reprod. 63: 440-447. [Medline] [CrossRef]

31. Jabbour, H.N., Clarke, L.A., McNeilly, A.S., Edery, M., and Kelly, P.A. 1998. Is prolactin a gonadotrophic hormone in red deer (Cervus elaphus)? Pattern of expression of the prolactin receptor gene in the testis and epididymis. J. Mol. Endocrinol. 20: 175-182. [Medline] [CrossRef]

32. Jaroenporn, S., Furuta, C., Nagaoka, K., Watanabe, G., and Taya, K. 2008. Comparative effects of prolactin versus $\mathrm{ACTH}$, estradiol, progesterone, testosterone, and dihydrotestosterone on cortisol release and proliferation of the adrenocortical carcinoma cell line H295R. Endocrine 33: 205-209. [Medline] [CrossRef]

33. Jaroenporn, S., Nagaoka, K., Kasahara, C., Ohta, R., Watanabe, G., and Taya, K. 2007. Physiological roles of prolactin in the adrenocortical response to acute restraint stress. Endocr. J. 54: 703-711. [Medline] [CrossRef]

34. Jaroenporn, S., Nagaoka, K., Ohta, R., Watanabe, G., and Taya, K. 2007. Direct effects of prolactin on adrenal steroid release in male Hatano high-avoidance (HAA) rats may be mediated through Janus kinase 2 (Jak2) activity. $J$. Reprod. Dev. 53: 887-893. [Medline] [CrossRef]

35. Jaroenporn, S., Nagaoka, K., Ohta, R., Shirota, M., Watanabe, G., and Taya, K. 2009. Differences in adrenocortical secretory and gene expression responses to stimulation in vitro by ACTH or prolactin between high- and low-avoidance Hatano rats. Stress 12: 22-29. [Medline] [CrossRef]

36. Jaroenporn, S., Nagaoka, K., Ohta, R., Watanabe, G., and Taya, K. 2009. Prolactin induces phosphorylation of the STAT5 in adrenal glands of Hatano rats during stress. Life Sci. 85: 172-177. [Medline] [CrossRef]

37. King, S.S., Dille, E.A., Marlo, T., Roser, J.F., and Jones, K.L. 2010. Ovarian prolactin activity: evidence of local action and production. Anim. Reprod. Sci. 1215: S51-S53.

38. King, S.S., Oberhaus, C.M., Welsh, D.T., Heath, K.L., and Jones, K.L. 2014. Evidence for local neuroendocrine signaling in ovarian prolactin regulation. J. Equine Vet. Sci.
34: 107-108. [CrossRef]

39. King, S.S., Roser, J.F., and Jones, K.L. 2008. Follicular fluid prolactin and the periovulatory prolactin surge in the mare. J. Equine Vet. Sci. 28: 468-472. [CrossRef]

40. Klemcke, H.G., Bartke, A., and Borer, K.T. 1984. Regulation of testicular prolactin and luteinizing hormone receptors in golden hamsters. Endocrinology 114: 594-603. [Medline] [CrossRef]

41. Korenman, S.G., Stevens, R.H., Carpenter, L.A., Robb, M., Niswender, G.D., and Sherman, B.M. 1974. Estradiol radioimmunoassay without chromatography: procedure, validation and normal values. J. Clin. Endocrinol. Metab. 38: 718-720. [Medline] [CrossRef]

42. Kunii, H., Nambo, Y., Okano, A., Matsui, A., Ishimaru, M., Asai, Y., Sato, F., Fujii, K., Nagaoka, K., Watanabe, G., and Taya, K. 2015. Effects of an extended photoperiod on gonadal function and condition of hair coats in Thoroughbred colts and fillies. J. Equine Sci. 26: 57-66. [Medline] [CrossRef]

43. Lemazurier, E., Toquet, M.P., Fortier, G., and Séralini, G.E.R. 2002. Sex steroids in serum of prepubertal male and female horses and correlation with bone characteristics. Steroids 67: 361-369. [Medline] [CrossRef]

44. Medan, M.S., Nambo, Y., Nagamine, N., Shinbo, H., Watanabe, G., Groome, N., and Taya, K. 2004. Plasma concentrations of ir-inhibin, inhibin A, inhibin pro-alphaC, $\mathrm{FSH}$, and estradiol-17 $\beta$ during estrous cycle in mares and their relationship with follicular growth. Endocrine 25: 7-14. [Medline] [CrossRef]

45. Mizukami, H., Suzuki, T., Nambo, Y., Ishimaru, M., Naito, H., Korosue, K., Akiyama, K., Miyata, K., Yamanobe, A., Nagaoka, K., Watanabe, G., and Taya, K. 2015. Comparison of growth and endocrine changes in Thoroughbred colts and fillies reared under different climate conditions. J. Equine Sci. 26: 49-56. [Medline] [CrossRef]

46. Nagamine, N., Nambo, Y., Nagata, S., Nagaoka, K., Tsunoda, N., Taniyama, H., Tanaka, Y., Tohei, A., Watanabe, G., and Taya, K. 1998. Inhibin secretion in the mare: localization of inhibin $\alpha$, betaA, and betaB subunits in the ovary. Biol. Reprod. 59: 1392-1398. [Medline] [CrossRef]

47. Nagata, S., Miyake, Y.I., Nambo, Y., Nagamine, N., Watanabe, G., Tsunoda, N., Taniyama, H., Hondo, E., Yamada, J., and Taya, K. 1998. Inhibin secretion in the stallion. Equine Vet. J. 30: 98-103. [Medline] [CrossRef]

48. Nagata, S., Tsunoda, N., Nagamine, N., Tanaka, Y., Taniyama, H., Nambo, Y., Watanabe, G., and Taya, K. 1998. Testicular inhibin in the stallion: cellular source and seasonal changes in its secretion. Biol. Reprod. 59: 62-68. [Medline] [CrossRef]

49. Nagy, P., Guillaume, D., and Daels, P. 2000. Seasonality in mares. Anim. Reprod. Sci. 60-61: 245-262. [Medline] [CrossRef]

50. Nambo, Y., Okano, A., Kunii, H., Harada, T., Dhakal, P., Matsui, A., Korosue, K., Yamanobe, A., Nagata, S., Wata- 
nabe, G., and Taya, K. 2010. Effect of extended photoperiod on reproductive endocrinology and body composition in Thoroughbred yearlings and weanlings. Anim. Reprod. Sci. 1215: 535-537.

51. Nequin, L.G., King, S.S., Jonson, A.L., Gow, G.M., and Ferreira-Dias, G.M. 1993. Prolactin may play a role in stimulating the equine ovary during the spring reproductive transition. J. Equine Vet. Sci. 13: 631-635. [CrossRef]

52. Nicks, K.M., Fowler, T.W., and Gaddy, D. 2010. Reproductive hormones and bone. Curr. Osteoporos. Rep. 8: 60-67. [Medline] [CrossRef]

53. Nishikawa, Y. 1959. Studies on Reproduction in Horses. Singularity and Artificial Control in Reproductive Phenomena. Japanese Racing Association, Tokyo.

54. Suntornsaratoon, P., Wongdee, K., Krishnamra, N., and Charoenphandhu, N. 2010. Possible chondroregulatory role of prolactin on the tibial growth plate of lactating rats. Histochem. Cell Biol. 134: 483-491. [Medline] [CrossRef]

55. Suntornsaratoon, P., Wongdee, K., Goswami, S., Krishnamra, N., and Charoenphandhu, N. 2010. Bone modeling in bromocriptine-treated pregnant and lactating rats: pos- sible osteoregulatory role of prolactin in lactation. Am. J. Physiol. Endocrinol. Metab. 299: E426-E436. [Medline] [CrossRef]

56. Taya, K. 2011. Stress and prolactin. Horm. Front. Gynecol. 18: $275-283$.

57. Taya, K., Watanabe, G., and Sasamoto, S. 1985. Radioimmunoassay for progesterone, testosterone and estradiol$17 \beta^{125}$ I-iodohistamine radioligands. Jpn. J. Anim. Reprod. 31: 186-197. [CrossRef]

58. Thompson, D.L. Jr., and DePew, C.L. 1997. Prolactin, gonadotropin, and hair shedding responses to daily sulpiride administration in geldings in winter. J. Anim. Sci. 75: 1087-1091. [Medline]

59. Thompson, D.L. Jr., Hoffman, R., and DePew, C.L. 1997. Prolactin administration to seasonally anestrous mares: reproductive, metabolic, and hair-shedding responses. $J$. Anim. Sci. 75: 1092-1099. [Medline]

60. Yoon, M.J., Berger, T., and Roser, J.F. 2011. Localization of insulin-like growth factor-I (IGF-I) and IGF-I receptor (IGF-IR) in equine testes. Reprod. Domest. Anim. 46: 221-228. [Medline] [CrossRef] 